\title{
АНАЛІЗ СТАНУ ПІДГОТОВКИ МАЙБУТНІХ МЕДИЧНИХ СЕСТЕР ЗАСОБАМИ КОМП'ЮТЕРНИХ ТЕХНОЛОГІЙ
}

\author{
В. А. Славопас
}

Приватний вищий навчальний заклад “Медичний коледж”, м. Тернопіль

\section{ANALYSIS OF PREPARATION OF FUTURE NURSES BY MEANS OF COMPUTER TECHNOLOGY}

\author{
V. A. Slavopas
}

\author{
Ternopil Medical College
}

\begin{abstract}
У статті описано розвиток системи охорони здоров'я на сучасному етапі, пов'язаний із використанням комп'ютерних технологій у профілактиці, діагностиці та лікуванні захворювань; проведено аналіз сучасного стану підготовки майбутніх медичних сестер засобами комп’ютерних технологій; розглянуто особливості викладання дисципліни “Основи медичної інформатики” у студентів спеціальності “Сестринська справа”; внесено пропозиції щодо посилення методичної складової процесу підготовки майбутніх медичних сестер до використання комп’ютерних технологій у професійній діяльності.

This paper describes the development of the health system at present associated with the use of computer technology in the prevention, diagnosis and treatment of diseases; analysis of the current state of training of future nurses by means of computer technology; the peculiarities of teaching "Basics of Medical Informatics" students majoring in "Nursing”; proposals to strengthen the methodological part of the process of preparing future nurses to use computer technology in professional activities.
\end{abstract}

Вступ. Одним із головних напрямів реформування системи охорони здоров’я в усьому світі й в Україні є інноваційний розвиток, пов’язаний із запровадженням сучасних комп'ютерних технологій у профілактиці, діагностиці та лікуванні захворювань. Водночас ефективний розвиток системи охорони здоров'я значною мірою залежить від стану професійного рівня і якості підготовки, раціонального розміщення та використання середнього медичного персоналу, зокрема медичних сестер, як найбільш об’ємної складової кадрового ресурсу охорони здоров'я. В умовах технологізованого суспільства принципово змінюються підходи до діяльності середнього медичного персоналу. Для допомоги пацієнтам необхідно освоювати все більш складні медичні і технічні знання, оволодівати новими навиками, а також удосконалювати вже набуті. Якість сестринської допомоги визначається втіленням нових організаційних форм з догляду за пацієнтами, стандартів і технологій практичної діяльності сестринського персоналу, умінням працювати з професійною інформацією, використовуючи сучасні комп’ютерні технології [1].

с В. А. Славопас
Основна частина. Потребу сучасного суспільства в медичних працівниках, які володіють мотивацією і готовністю до застосування комп’ютерних технологій, можна визначити, аналізуючи процес використання комп’ютерних технологій у медицині i, зокрема, в діагностичному процесі.

Розвиток нових методів діагностики привів до створення складної медичної апаратури та спеціалізованих комп’ютерних програм. Широке застосування отримали такі методи діагностики, як: комп'ютерна мамографія, комп'ютерна томографія, магнітно-резонансна томографія, позитронноемісійна томографія, електронна дерматоскопія, конфокальна мікроскопія, оптична когерентна томографія, пряме оптичне сканування, комп'ютерна електрокардіографія, комп'ютерна електроенцефалографія, комп’ютерна реографія, комп’ютерна рентгенографія (ангіографія, дуктографія, іригографія, іригоскопія, краніографія, лімфографія, метросальпінгографія, цистографія), ультразвукове дослідження, застосування портативного ручного приладу для визначення периферичних вен тощо [2].

Проте існує певне відставання щодо оснащення державних закладів охорони здоров’я сучасною 
комп’ютерною технікою, не вистачає підготовленого до роботи з сучасними приладами середнього медичного персоналу.

Рівень грамотності кваліфікованої медичної сестри включає ряд складових, у тому числі вміння використовувати комп’ютерні технології для отримання, передачі, зберігання і первинної обробки інформації. Комп’ютерна грамотність передбачає наявність у сучасного спеціаліста таких сформованих вмінь і навичок, як:

- володіння клавіатурою і маніпулятором-мишкою;

- вміння створювати текстовий і графічний документи;

- вміння користуватися графічним пристроєм введення/виведення;

- вміння використовувати можливості графічних технологій;

- вміння приймати та пересилати електронні повідомлення;

- вміння використовувати можливості мережі "Інтернет";

- вміння користуватися мультимедійними системами;

- вміння вибирати конфігурацію комп’ютера та інформаційного середовища;

- вміння користуватися послугами інформаційних систем широкого застосування [3].

Освіта слугує основою для оволодіння вміннями використовувати комп'ютерні технології. Тому комп’ютерна грамотність - це мінімальний рівень професійної підготовки майбутніх медичних сестер, який повинна забезпечувати медична освіта.

Однією з особливостей вивчення комп’ютерних технологій є висока динаміка розвитку сучасних засобів обробки інформації і комп’ютерних комунікацій, постійно відбувається удосконалення параметрів комп’ютерного та програмного забезпечення. При цьому відповідно до навчального плану підготовка студентів до застосування комп’ютерних технологій здійснюється лише під час вивчення дисципліни “Основи медичної інформатики” на II курсі. Таким чином, створюється розрив між вимогами, які диктує сучасна медицина, та підготовкою студентів до застосування комп’ютерних технологій. В програмі навчальної дисципліни “Основи медичної інформатики”, яка розроблена державною установою “Центральний методичний кабінет” МO3 України, виділено лише 81 годину, з них 36 год (лекції- 8 год; практичні заняття - 12 год; самостійна робота - 16 год) на вивчення таких тем, як “Медичні комп’ютерні комунікації”, “Медичні інфор- маційні системи”, “Медичні приладо-комп’ютерні системи”, “Медичні комп’ютерні системи візуалізації”. Після вивчення цих тем студенти повинні знати: медичні інформаційні системи лікувальних закладів, які використовуються в місті, сучасні комп’ютерні методи обстеження та лікування, які використовуються в Україні, принципи роботи в локальних мережах і в мережі Internet; студенти повинні вміти: запускати на виконання й використовувати програми для підтримки розв’язування медичних завдань за допомогою ОC Windows-95, 98, XP та програми-оболонки FAR, користуватися автоматизованою системою профогляду і диспансеризації населення, яка використовується в місті, заповнювати картки згідно з анкетою й друкувати вихідні документи; працювати в мережі Internet, 3 електронною поштою або в локальній мережі лікувального закладу, здійснювати пошук медичної інформації; студенти мають бути поінформовані про: сучасні тепловізорні, ультразвукові обстеження, рентгенівську, магніторезонансну та радіонуклідну комп’ютерну томографію, планувальні дозиметричні системи (ПДС) у променевих процедурах як моделювальні комп’ютерні системи.

3 метою виявлення рівня знань серед студентів медичного коледжу II, III та IV курсів (відповідно, 51, 53 та 52 студенти) спеціальності “Сестринська справа” був проведений зріз знань з дисципліни “Основи медичної інформатики”. Кожному студенту потрібно було відповісти на 20 тестових завдань та виконати 2 практичних завдання. За результатами аналізу зрізу знань (рис.), студенти отримали такі оцінки: II курс: “відмінно” - 3 студенти, “добре” - 27 студентів, “задовільно” - 17 студентів, “незадовільно” - 4 студенти; III курс: “відмінно” 1 студент, “добре” - 10 студентів, “задовільно” 37 студентів, “незадовільно” - 5 студентів; IV курс: “відмінно” - 0 студентів, “добре” - 8 студентів,

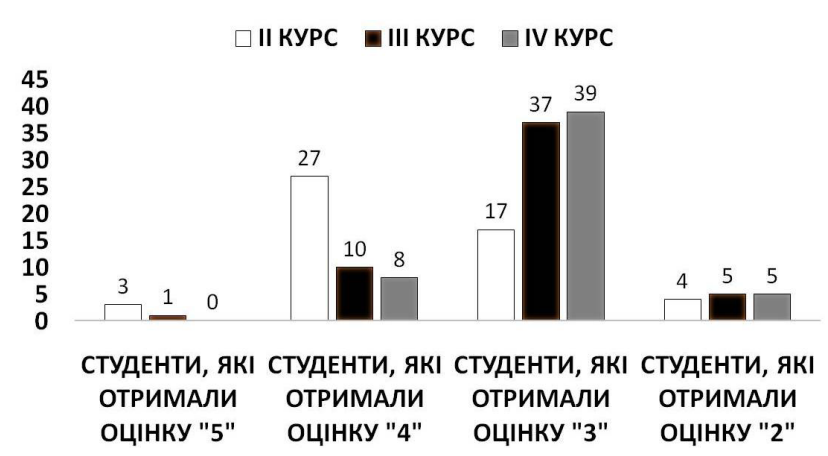

Рис. Результати зрізу знань студентів 3 дисципліни “Основи медичної інформатики”. 
“задовільно” - 39 студентів, “незадовільно” 5 студентів. Середній бал, відповідно, на II курсі 3,6; на III курсі - 3,1; на IV курсі - 3,0.

Робимо висновок, що у студентів старших курсів суттєво знижується рівень знань з дисципліни “Основи медичної інформатики”. Таким чином, підготовка майбутніх медичних сестер до застосування комп'ютерних технологій повинна бути пов'язана не лише з формуванням інформаційної компетентності з дисципліни “Основи медичної інформатики”, але, головним чином, з формуванням здатності і готовності застосовувати комп’ютерні технології в професійній діяльності.

Висновки. Підготовка студентів до використання комп’ютерних технологій у практичній роботі повинна визначатися видами діяльності, які відповідають кваліфікації майбутніх спеціалістів. Тому,

\section{Список літератури}

1. Маркович О. В. Сучасний стан підготовки медичної сестри в Україні і шляхи його покращання / О. В. Маркович, В. О. Рижковський // Клінічна та експериментальна патологія. - 2011. - Т. 10. - С. 25-28.

2. Островская И. В. Медицинские сестры и инновационные технологии в здравоохранении / И. В. Островская // Мед. сестра. - 2009. - № 3. - С. 4-9. щоб вивчення комп'ютерних технологій було адекватне вимогам сьогодення, виникає необхідність у безперервній, багаторівневій підготовці майбутніх медичних сестер. Виходячи з високої динаміки розвитку комп’ютерних технологій, потреб системи охорони здоров'я, вважаємо, що професійна підготовка майбутніх медичних сестер повинна передбачати вивчення комп’ютерних технологій у процесі всього періоду навчання, бути багатоетапною і забезпечувати різні рівні підготовки. Виникає необхідність посилення методичної складової процесу підготовки майбутніх медичних сестер до використання комп'ютерних технологій, а саме введення додаткових факультативів, проведення лабораторних робіт, використання комп’ютерних технологій під час викладання клінічних дисциплін, розробка електронних методичних посібників та ін. [4].

3. Гараничева С. Л. Теория и практика подготовки студентов медицинских вузов к применению информационных технологий (монография) / С. Л. Гараничева. - Витебск : ВГМУ, 2004. - С. 36-37.

4. Ратушняк Д. Ю. Непрерывное сопровождение информационной подготовки студентов медицинского колледжа / Д. Ю. Ратушняк // Новый университет. 2013. - № 9.- С. 66-69. 